\title{
Analisis VAR (Vector Autograsive) Permintaan Dan Penawaran Kunjungan Wisatawan Domestik Di Kabupaten Lombok Utara (KLU)
}

\section{Himawan Sutanto}

Universitas Mataram

ARTICLE INFO

Keywords :

Supply and Demand, Tourist Visits, North VAR Analysis (Vector Autograsive) Lombok Regency (KLU),

Received : 15 Januari 2018; Accepted: 27 Februari 2018; Published: Maret 2018

ABSTRACT : This research is entitled "Analysis of VAR (Vector Autograsive) Requests and Offers of Tourist Visits in North Lombok Regency (KLU)". The formulation of the problem in this study are (a) whether the variables that determine the demand and supply of tourists in North Lombok Regency (KLU), (b) are the variables that determine the demand and supply of tourists in North Lombok Regency (KLU)? (a) to find out the variables that determine the demand and supply of tourist visits in North Lombok Regency (KLU), (b) to find out the variables that most determine the demand and supply of tourist visits in North Lombok Regency (KLU. Data used in this study Secondary data from KLU Tourism Office, NTB Central Bureau of Statistics (BPS), Bank Indonesia The research variables used were tourist visit requests and offers in North Lombok Regency (KLU) such as NTB Inflation Rate, NTB GRDP, KLU Inflation, GRDP KLU The data analysis technique used in this research is VAR Analysis (Vector Autograsive) with $b$ ante software Eviews. The results of the study showed that the Province Inflation Variables, Provincial GRDP had a significant effect on Domestic Tourist requests in North Lombok Regency (KLU).
Kata Kunci :

Permintaan dan

Penawaran, Kunjungan

Wisatawan, Kabupaten

Lombok Utara (KLU),

Analisis VAR (Vector

Autograsive)

ABSTRAK : Penelitian ini berjudul "Analisis VAR (Vector Autograsive) Permintaan dan Penawaran Kunjungan Wisatawan Di Kabupaten Lombok Utara (KLU)". Rumusan masalah dalam penelitian ini adalah (a) apakah variable-variabel yang menentukan permintaan dan penawaran wisatawan di Kabupaten Lombok Utara (KLU), (b) apakah variabel yang paling menentukan permintaan dan penawaran wisatawan di Kabupaten Lombok Utara (KLU) Tujuan penelitian ini adalah (a) untuk mengetahui variablevariabel yang menentukan permintaan dan penawaran kunjungan wisatawan di Kabupaten Lombok Utara (KLU), (b) untuk mengetahui variabel yang paling menentukan permintaan dan penawaran kunjungan wisatawan di Kabupaten Lombok Utara (KLU. Data yang digunakan dalam penelitian ini adalah data sekunder yang berasal dari Dinas Pariwisata KLU, Badan Pusat Statistik (BPS) NTB, Bank Indonesia. Variabel Penelitian yang digunakan adalah permintaan dan penawaran kunjungan wisatawan di Kabupaten Lombok Utara (KLU) seperti Tingkat Inflasi NTB, PDRB NTB, Inflasi KLU, PDRB KLU. Teknik analisis data yang digunakan dalam penelitian ini adalah Analisis VAR (Vector Autograsive) dengan bantuan software Eviews. Hasil Penelitian menunjukkan bahwa Variabel Inflasi Provinsi, PDRB Provinsi memiliki pengaruh yang signifikan terhadap Permintaan kunjungan wisatawan Domestik di Kabupaten Lombok Utara (KLU).

Corresponding Author :

Alamat : Program Studi Ekonomi Pembangunan, Fakultas Ekonomi dan Bisnis, Universitas Mataram, Jln. Majapahit No. 62 Mataram.

e-mail: Himawan@gmail.com 


\section{PENDAHULUAN}

\section{Latar Belakang}

Sektor pariwisata sangat penting dikembangkan karena memiliki peranan yang sangat penting dalam perekonomian, dimana pada tahun 2007 sumbangannya terhadap Produk Domestik Bruto (PDB) cukup besar yang mencapai $3,7 \%$, sumbangan yang cukup besar ini harus diimbangi oleh pemerintah melalui kebijakan kepariwisataan yang sesuai dengan kebutuhan sektor pariwisata saat ini, karena dunia pariwisata saat ini sangat cepat berubah terutama yang berkaitan dengan wisatawan asing karena memiliki perilaku yang cukup dinamis dalam memilih atau mencari daerah wisata yang akan dikunjunginya. Pengembangan pariwisata harus memiliki sinergitas antara kebijakan pemerintah pusat dengan kebijakan pemerintah daerah (Pemda) agar seluruh program pengembangan pariwisata tersebut dapat tercapai dengan baik. Suatu Kebijakan pengembangan pariwisata oleh pemerintah pusat maupun daerah (PEMDA) terlihat dari jumlah kunjungan wisatawan, baik wisatawan domestic (lokal dan nasional) maupun wisatawan asing (Luar Negeri), semakin banyak jumlah kunjungan wisatawan kesuatu daerah wisata maka semakin baik juga pengembangan pariwisata oleh pemerintah daerah dan sebaliknya semakin berkurang jumlah kunjungan wisatawan kesuatu daerah maka kebijakan pengembangan pariwisatanya semakin tidak baik, oleh karena itu jumlah kunjungan wisatawan menjadi kunci keberhasilan kebijakan pemerintah pada sektor pariwisata.

Pengembangan sektor pariwisata dilakukan juga oleh Pemerintah kabupaten Lombok utara (KLU) yang menjadikan pariwisata sebagai sektor unggulan karena potensi wisata yang dimiliki oleh kabupaten Lombok utara cukup banyak dan memiliki potensi yang cukup besar yang terlihat pada tabel 1.1 dibawah ini. 
Tabel 1 Nama dan jenis beberapa objek wisata di kabupaten Lombok utara (KLU) 2013

\begin{tabular}{|l|l|l|}
\hline Kecamatan & Nama objek wisata & Jenis objek wisata \\
\hline 1.Pemenang & Gili Tramena (Trawangan, Meno, Air) & Alam/Pantai \\
& Goa Jepang Gili Trawangan & Alam/Sejarah \\
& Hutan Wisata Pusuk & Alam/Hutan \\
& Teluk Nara & Alam/Pantai \\
& Alam/Pantai \\
\hline 2.Tanjung & b. Pantai Sire & Alam/Pantai \\
& b. Arung Jeram Tengak Pekatan & Minat Khusus \\
\hline 3.Gangga & a. Pantai Kerakas & Alam/Pantai \\
& b. Dusun Selelos Budaya & Budaya \\
& c. Air Terjun Kerta Raharja & Alam/Pegunungan \\
& d. Air Terjun Tiu Pupus & Alam/Pegunungan \\
& e. Pantai Lempenge & Alam/Pantai \\
& f. Pantai Montong Pal & Alam/Pantai \\
\hline 4.Kayangan & a. Air Terjun Tiu Teja & Alam/Pegunungan \\
& b. Air Terjun Sesait & Alam/Pegunungan \\
& c. Masjid Kuno Sesait & Budaya \\
\hline 5.Bayan & a. Air Terjun Sindang Gila & Alam/Pegunungan \\
& b. Air Terjun Tiu Kelep & Alam/Pegunungan \\
& c. Air Terjun Torean & Alam/Pegunungan \\
& d. Masjid Kuno Bayan Beleq & Budaya \\
& e. Desa Tradisional Senaru & Budaya \\
& f. Desa Tradisional Segenter & Budaya \\
& g. Taman Nasional Gunung Rinjani & Alam/Pegunungan \\
& h. Pantai Tanjung Menangis & Alam/Pantai \\
& & \\
\hline
\end{tabular}

Sumber : KLU dalam Angka 2013

Dari tabel 1.1 diatas tersebut terlihat bahwa cukup banyak potensi pariwisata yang dimiliki oleh kabupaten Lombok utara, terutama wisata pantai yang cukup terkenal dikalangan wisatawan seperti tiga gili yang memiliki wisata pantai yang indah yaitu gili tramena (Trawangan, Meno, Air) yang terletak dikecamatan Pemenang, selain itu juga banyak juga potensi yang belum digarap secara maksimal oleh pemerintah daerah seperti objek wisata yang berada di wilayah kecamatan tanjung, gangga, kayangan dan bayan yang memiliki wisata alam, pantai, pegunungan,dan budaya. Potensi wisata yang cukup besar tersebut akan mendatangkan manfaat ekonomi bagi pemerintah maupun masyarakat sekitar. Agar dapat mendatangkan manfaat ekonomi maka perlu adanya perhatian dari pemerintah daerah dengan mengeluarkan kebijakan-kebijakan dalam mengembangkan potensi pariwisata di kabupaten Lombok utara, salah satu 
indikator keberhasilan dalam pariwisata

disuatu daerah.

adalah jumlah kunjungan wisatawan

Grafik 1 Jumlah kunjungan wisatawan di Kabupaten Lombok Utara (KLU)

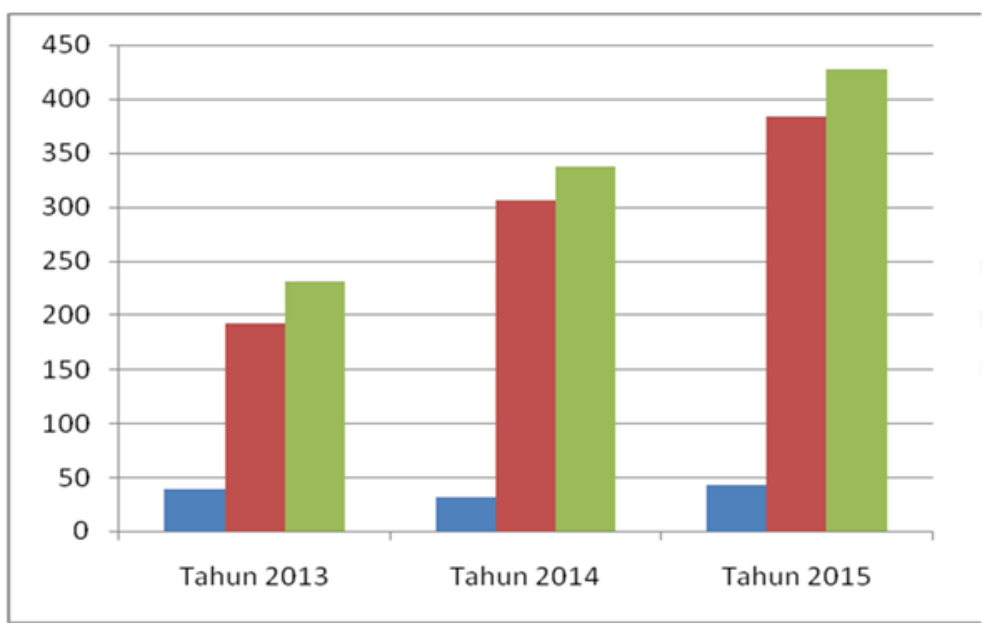

Sumber : KLU dalam Angka 2016 (Diolah)

Berdasarkan gafik 2 diatas terlihat bahwa jumlah kunjungan wisatawan di kabupaten Lombok utara mengalami kenaikan dimana pada tahun 2010 jumlah wisatawan asing maupun domestic berjumlah 230.767 orang sedangkan pada tahun 2012 jumlah kunjungan wisatawan asing maupun domestic berjumlah 426.969 orang, artinya kabupaten Lombok utara memiliki pariwisata yang disukai oleh para wisatawan asing maupun domestic atau menjadi tujuan utama bagi para wisatawan.

Untuk meningkatkan jumlah kunjungan wisatawan ke kabupaten Lombok utara maka perlu terlebih dahulu mengidentifikasi dan mengetahui faktorfaktor yang mempengaruhi kunjungan wisatawan ke kabupaten Lombok utara untuk dapat membuat formulasi kebijakan-kebijakan yang mendukung peningkatan jumlah wisatawan di kabupaten Lombok utara, oleh karena itu diperlukan penelitian yang berkaitan dengan "Analisis VAR (Vector Autograsive) Permintaan dan Penawaran Kunjungan Wisatawan Di Kabupaten Lombok Utara $(K L U)^{\prime \prime}$.

\section{Perumusan Masalah}

Dari uraian di atas dapat diambil pokok permasalahannya yaitu:

1. Variable-variabel apakah yang menentukan permintaan dan penawaran wisatawan di Kabupaten Lombok Utara (KLU)

2. Variabel apakah yang paling menentukan permintaan dan 
penawaran wisatawan di Kabupaten

Lombok Utara (KLU)

\section{Tujuan Penelitian}

1. Untuk mengetahui Variable-variabel apakah yang menentukan permintaan dan penawaran kunjungan wisatawan di Kabupaten Lombok Utara (KLU)

2. Untuk mengetahui Variabel apakah yang paling menentukan permintaan dan penawaran kunjungan wisatawan di Kabupaten Lombok Utara (KLU)

Manfaat penelitian ini adalah:

1. Membantu dinas pariwisata kabupaten lombok utara dalam

meningkatkan kunjungan wisatawan ke kabupaten lombok utara

2. Membantu pemerintah kabupaten Lombok utara dalam mengembangkan pariwisata di kabupaten Lombok utara

3. Secara teoritis sebagai tambahan refrensi bagi pihak-pihak yang ingin melakukan penelitian lebih lanjut berkaitan dengan Faktor-faktor yang mempengaruhi jumlah kunjungan wisatawan ke Kabupaten Lombok Utara

\section{TINJAUAN PUSTAKA}

\section{Penelitian Terdahulu}

Tabel 2 Penelitian Terdahulu

\begin{tabular}{|c|c|c|c|c|}
\hline $\begin{array}{c}\text { Penulis \& } \\
\text { tahun }\end{array}$ & Judul & $\begin{array}{c}\text { Tujuan } \\
\text { penelitian }\end{array}$ & $\begin{array}{l}\text { Metode } \\
\text { Penelitian }\end{array}$ & Kesimpulan \\
\hline $\begin{array}{l}\text { Sharifi \& } \\
\text { Gilaninia } \\
(2013)\end{array}$ & $\begin{array}{l}\text { Economic } \\
\text { Factors } \\
\text { Affecting } \\
\text { Tourism } \\
\text { Supply }\end{array}$ & $\begin{array}{l}\text { untuk } \\
\text { mengetahui } \\
\text { pengaruh } \\
\text { faktor-faktor } \\
\text { ekonomi } \\
\text { terhadap } \\
\text { penawaran } \\
\text { pariwisata di } \\
\text { Iran }\end{array}$ & $\begin{array}{l}\text { Regresi log } \\
\text { linier } \\
\text { berganda }\end{array}$ & $\begin{array}{l}\text { Terdapat hubungan yang } \\
\text { signifikan antara pendapatan } \\
\text { per kapita rumah tangga } \\
\text { perkotaan dan jumlah } \\
\text { penawaran pariwisata di Iran } \\
\text { dan juga ada hubungan yang } \\
\text { signifikan antara nilai tukar } \\
\text { dengan jumlah penawaran } \\
\text { pariwisata di Iran dengan } \\
\text { Pendapatan perkapita memiliki } \\
\text { faktor yang paling penting } \\
\text { dalam mempengaruhi } \\
\text { penawaran pariwisata di Iran. }\end{array}$ \\
\hline $\begin{array}{l}\text { Ibrahim } \\
\text { (2011) }\end{array}$ & $\begin{array}{l}\text { The } \\
\text { Determinan } \\
\text { ts of } \\
\text { Internation } \\
\text { al Tourism } \\
\text { Demand for }\end{array}$ & $\begin{array}{l}\text { untuk } \\
\text { mengetahui } \\
\text { faktor-faktor } \\
\text { penentu } \\
\text { utama dari } \\
\text { wisatawan }\end{array}$ & $\begin{array}{l}\text { Regresi log } \\
\text { linier } \\
\text { berganda }\end{array}$ & $\begin{array}{l}\text { PDB memiliki pengaruh yang } \\
\text { signifikan positif, nilai tukar } \\
\text { dan tingkat harga memiliki } \\
\text { pengaruh yang signifikan } \\
\text { negative terhadap jumlah } \\
\text { kunjungan wisatawan asing di }\end{array}$ \\
\hline
\end{tabular}




\begin{tabular}{|c|c|c|c|c|}
\hline & $\begin{array}{l}\text { Egypt: } \\
\text { Panel Data } \\
\text { Evidence }\end{array}$ & $\begin{array}{l}\text { internasional } \\
\text { di Mesir }\end{array}$ & & Mesir. \\
\hline $\begin{array}{l}\text { Gabroveanu } \\
\text {,et.al, } \\
\text { (2010) }\end{array}$ & $\begin{array}{l}\text { Analysis of } \\
\text { Main } \\
\text { Economic } \\
\text { Factors } \\
\text { Influence } \\
\text { on } \\
\text { Romanian } \\
\text { Tourists } \\
\text { Number } \\
\text { Accommod } \\
\text { ated in } \\
\text { Romania, } \\
\text { using } \\
\text { Anova } \\
\text { Method }\end{array}$ & $\begin{array}{l}\text { untuk } \\
\text { mengidentifika } \\
\text { si pengaruh } \\
\text { faktor } \\
\text { ekonomi } \\
\text { utama seperti } \\
\text { total } \\
\text { pendapatan } \\
\text { rumah tangga } \\
\text { dan indeks } \\
\text { harga } \\
\text { konsumen } \\
\text { terhadap } \\
\text { jumlah } \\
\text { wisatawan di } \\
\text { Rumania pada } \\
\text { periode 2001- } \\
2007\end{array}$ & $\begin{array}{l}\text { Analisis } \\
\text { regresi } \\
\text { linier } \\
\text { berganda } \\
\text { \& ANOVA }\end{array}$ & $\begin{array}{l}\text { jumlah wisatawan yang } \\
\text { berkunjung ke Rumania dan } \\
\text { total pendapatan rumah } \\
\text { tangga, dan indek harga } \\
\text { konsumen Memiliki hubungan } \\
\text { yang sangat kuat dengan } \\
\text { korelasi memiliki nila } \\
\text { 0,974653. Dimana IHK memilik } \\
\text { hubungan yang paling kuat } \\
\text { sehingga Harga (IHK) yang } \\
\text { lebih rendah } \\
\text { menyebabkanpeningkatan } \\
\text { permintaan pariwisata } \\
\text { (peningkatan jumlah } \\
\text { wisatawan, lama tinggal, } \\
\text { frekuensi perjalanan semakin } \\
\text { banyak), dan begitupun } \\
\text { sebaliknya. }\end{array}$ \\
\hline Tse (2001) & $\begin{array}{l}\text { Estimating } \\
\text { the impact } \\
\text { of } \\
\text { economic } \\
\text { factors on } \\
\text { tourism: } \\
\text { evidence } \\
\text { from Hong } \\
\text { Kong }\end{array}$ & $\begin{array}{l}\text { Untuk } \\
\text { mengetahui } \\
\text { pengaruh } \\
\text { faktor-faktor } \\
\text { ekonomi } \\
\text { terhadap } \\
\text { pengeluaran } \\
\text { wisatawan dan } \\
\text { tingkat hunian } \\
\text { kamar hotel } \\
\text { studi kasus di } \\
\text { Hongkong. }\end{array}$ & $\begin{array}{l}\text { Regresi } \\
\text { linier } \\
\text { berganda }\end{array}$ & $\begin{array}{l}\text { pengeluaran pariwisata } \\
\text { dipengaruhi oleh pendapatan } \\
\text { yang diharapkan, nilai tukar } \\
\text { yang diharapkan dan tingkat } \\
\text { harga (inflasi). Selain itu juga } \\
\text { Tingkat hunian hote } \\
\text { dipengaruhi oleh variabel nila } \\
\text { tukar, tingkat harga, tingkat } \\
\text { hunian dan lama tingga } \\
\text { wisatawan di Hongkong. }\end{array}$ \\
\hline $\begin{array}{l}\text { I Nengah } \\
\text { Wijaya } \\
(2011)\end{array}$ & $\begin{array}{l}\text { Pengaruh } \\
\text { Jumlah } \\
\text { Wisatawan } \\
\text { Mancanage } \\
\text { ra, Lama } \\
\text { Tinggal, } \\
\text { Dan Kurs } \\
\text { Dollar } \\
\text { Amerika } \\
\text { Terhadap } \\
\text { Penerimaan } \\
\text { PDRB } \\
\text { Industry }\end{array}$ & $\begin{array}{l}\text { untuk } \\
\text { mengetahui } \\
\text { pengaruh } \\
\text { jumlah } \\
\text { wisatawan } \\
\text { mancanagera } \\
\text {,lama tinggal, } \\
\text { dan kurs dollar } \\
\text { Amerika } \\
\text { terhadap } \\
\text { penerimaan } \\
\text { produk } \\
\text { domestik }\end{array}$ & $\begin{array}{l}\text { Regresi } \\
\text { linier } \\
\text { berganda }\end{array}$ & $\begin{array}{l}\text { secara parsial jumlah } \\
\text { wisatawan manca negara, dan } \\
\text { kurs dolar Amerika } \\
\text { berpengaruh nyata dan positif } \\
\text { terhadap penerimaan Produk } \\
\text { Domestik Regional Bruto } \\
\text { industri pariwisata Kabupaten } \\
\text { Badung, sedangkan lama } \\
\text { tinggal berpengaruh tidak } \\
\text { nyata terhadap penerimaan } \\
\text { Produk Domestik Regiona } \\
\text { Bruto industri pariwisata } \\
\text { Kabupaten Badung. Secara }\end{array}$ \\
\hline
\end{tabular}




\begin{tabular}{|c|c|c|c|c|}
\hline & $\begin{array}{l}\text { Pariwisata } \\
\text { Kabupaten } \\
\text { Badung } \\
\text { Tahun } \\
\text { 1997-2010 }\end{array}$ & $\begin{array}{l}\text { regional bruto } \\
\text { industry } \\
\text { pariwisata } \\
\text { Kabupaten } \\
\text { Badung tahun } \\
1997-2010\end{array}$ & & $\begin{array}{l}\text { simultan jumlah wisatawan } \\
\text { mancanegara, lama tinggal, } \\
\text { dan kurs dolar Amerika } \\
\text { berpengaruh nyata terhdap } \\
\text { penerimaan Produk Domestik } \\
\text { Regional Bruto industri } \\
\text { pariwisata Kabupaten Badung }\end{array}$ \\
\hline $\begin{array}{l}\text { Eka Armoni } \\
\text { (2011) }\end{array}$ & $\begin{array}{l}\text { Pengaruh } \\
\text { Pendapatan } \\
\text { Per Kapita, } \\
\text { Nilai Tukar, } \\
\text { Dan } \\
\text { Keamanan } \\
\text { Terhadap } \\
\text { Jumlah } \\
\text { Kunjungan } \\
\text { Wisatawan } \\
\text { Korea } \\
\text { Selatan Ke } \\
\text { Bali }\end{array}$ & $\begin{array}{l}\text { untuk } \\
\text { mengetahui } \\
\text { Pengaruh/hub } \\
\text { ungan antara } \\
\text { Pendapatan } \\
\text { Per Kapita, } \\
\text { Nilai Tukar, } \\
\text { Dan Keamanan } \\
\text { Terhadap } \\
\text { Jumlah } \\
\text { Kunjungan } \\
\text { Wisatawan } \\
\text { Korea Selatan } \\
\text { Ke Bali }\end{array}$ & $\begin{array}{l}\text { Regresi } \\
\text { linier } \\
\text { berganda }\end{array}$ & $\begin{array}{l}\text { variabel pendapatan perkapita } \\
\text { (income percapita) dan nilai } \\
\text { tukar berpengaruh signifikan } \\
\text { terhadap jumlah kunjungan } \\
\text { wisatawan korea ke bali } \\
\text { sedangkan variabel keamanan } \\
\text { tidak berpengaruh terhadap } \\
\text { terhadap jumlah kunjungan } \\
\text { wisatawan korea ke bali. }\end{array}$ \\
\hline
\end{tabular}

\section{Landasan Teori}

\section{Pariwisata}

Menurut Undang-undang No. 10 Tahun 2009 tentang kepariwisataan, Pengertian pariwisata adalah berbagai macam kegiatan wisata dan didukung berbagai fasilitas serta layanan yang disediakan oleh masyarakat, pengusaha, pemerintah, dan pemerintah daerah.

Pengertian lain dari Pariwisata menyebutkan bahwa periwisata adalah suatu perjalanan yang dilakukan untuk sementara waktu, yang diselenggarakan dari suatu tempat lain, dengan maksud bukan untuk mencari nafkah di tempat yang dikunjungi, tetapi semata-mata untuk menikmati perjalanan hidup guna bertamasya dan berkreasi untuk memenuhi keinginan yang beraneka ragam (Yoeti,2006).

Sedangkan Marpaung (2002) mendifinisikan pariwisata sebagai perpindahan sementara yang dilakukan manusia dengan tujuan keluar dari pekerjaan-pekerjaan rutin, keluar dari tempat kediamannya. Aktivitas dilakukan selama mereka tinggal di tempat yang dituju dan fasilitas yang dibuat untuk memenuhi kebutuhan mereka.

Soekadijo (1997) mendifinisikan pariwisata sebagai segala kegiatan dalam masyarakat yang berhubungan dengan wisatawan. Semua kegiatan 
pembangunan hotel, pemugaran cagar budaya, pembuatan pusat rekreasi, penyelenggaraan pekan pariwisata, penyediaan angkutan dan sebagainya semua itu dapat disebut kegiatan pariwisata sepanjang dengan kegiatankegiatan itu semua dapat diharapkan para wisatawan akan datang.

Menurut World Tourism Organization (WTO) pariwisata adalah kegiatan seseorang yang bepergian ke atau tinggal di suatu tempat di luar lingkungannya yang biasa dalam waktu tidak lebih dari satu tahun secara terus menerus, untuk kesenangan, bisnis ataupun tujuan lainnya. (Pitana, 2009)

\section{Jenis-Jenis Pariwisata}

Menurut Pendit (1999) pariwisata dibagi menjadi beberapa jenis, antara lain: pariwisata menjadi beberapa jenis yaitu :

a. Wisata Industri, Perjalanan yang dilakukan oleh rombongan pelajar atau mahasiswa, atau orang-orang awam ke suatu kompleks atau daerah perindustrian dimana terdapat pabrikpabrik atau bengkel-bengkel besar dengan maksud tujuan untuk mengadakan peninjauan atau penelitian. Misalnya, rombongan pelajar yang mengunjungi industri tekstil.

b. Wisata Politik, Perjalanan yang dilakukan untuk mengunjungi atau mengambil bagian aktif dalam peristiwa kegiatan politik. Misalnya, ulang tahun 17 Agustus di Jakarta, Perayaan 10 Oktober di Moskow,

Penobatan Ratu Inggris, Perayaan Kemerdekaan, Kongres atau konvensi politik yang disertai dengan darmawisata.

c. Wisata Konvensi, Perjalanan yang dilakukan untuk melakukan konvensi atau konferensi. Misalnya APEC, KTT non Blok.

d. Wisata Sosial, Merupakan pengorganisasian suatu perjalanan murah serta mudah untuk memberi kesempatan kepada golongan masyarakat ekonomi lemah untuk mengadakan perjalanan seperti kaum buruh, pemuda, pelajar atau 
mahasiswa, petani dan sebagainya.

e. Wisata

Pertanian,

Merupakan pengorganisasian perjalanan yang dilakukan ke proyek-proyek pertanian, perkebunan, ladang pembibitan dan sebagainya dimana wisatawan rombongan dapat mengadakan kunjungan dan peninjauan untuk tujuan studi maupun melihat-lihat keliling sambil menikmati segarnya tanaman beraneka ragam warna dan suburnya pembibitan di tempat yang dikunjunginya.

f. Wisata Budaya, Merupakan perjalanan wisata atas dasar keinginan untuk memperluas pandangan seseorang dengan mengadakan kunjungan atau peninjauan ke tempat lain atau ke luar negeri, mempelajari keadaan rakyat, kebiasaan dan adat istiadat mereka.

g. Wisata Kesehatan, Hal ini dimaksudkan dengan perjalanan seorang wisatawan dengan tujuan untuk menukar keadaan dan lingkungan tempat seharihari di mana ia tinggal demi kepentingan beristirahat baginya dalam arti jasmani dan rohani dengan mengunjungi tempat peristirahatan seperti mata air panas mengandung mineral yang dapat menyembuhkan, tempat yang memiliki iklim udara menyehatkan atau tempat yang memiliki fasilitasfasilitas kesehatan lainnya.

\section{h. Wisata Olah Raga,} Wisatawan yang melakukan perjalanan dengan tujuan berolahraga atau. memang sengaja bermaksud mengambil bagian aktif dalam peserta olahraga disuatu tempat atau Negara seperti Asian Games, Olympiade, Thomas Cup, Uber Cup dan lain-lain. Bisa saja olah raga memancing, berburu, berenang.

i. Wisata Komersial, Dalam jenis ini termasuk perjalanan untuk mengunjungi pameran-pameran dan 
pekan raya yang bersifat komersial, seperti pameran industri, pameran dagang dan sebagainya.

j. Wisata Maritim (Marina) atau Bahari, Wisata yang dikaitkan dengan kegiatan olah raga di air, lebih-lebih danau, bengawan, teluk atau laut. Seperti memancing, berlayar, menyelam, berselancar, balapan mendayung dan lainnya.

k. Wisata Cagar Alam, Wisata ini biasanya diselenggarakan oleh agen atau biro perjalanan yang mengkhususkan usaha-usaha dengan jalan mengatur wisata ke tempat atau daerah cagar alam, tanaman lindung, hutan daerah pegunungan dan sebagainya.

I. Wisata Buru, Wisata untuk buru, ditempat atau hutan yang telah ditetapkan pemerintah Negara yang bersangkutan sebagai daerah perburuan, seperti di Baluran, Jawa Timur untuk menembak babi hutan atau banteng. m. Wisata Pilgrim, Jenis wisata ini dikaitkan dengan agama, sejarah, adat-istiadat dan kepercayaan umat atau kelompok dalam masyarakat Ini banyak dilakukan oleh rombongan atau perorangan ketempat-tempat suci, ke makam-makam orang besar, bukit atau gunung yang dianggap keramat, tempat pemakaman tokoh atau pimpinan yang dianggap legenda. Contoh makam Bung Karno di Blitar, Makam Wali Songo, tempat ibadah seperti di Candi Borobudur, Pura Besakih di Bali, Sendang Sono di Jawa Tengah dan sebagainya.

n. Wisata Bulan Madu, Suatu penyelenggaraan perjalanan bagi pasangan-pasangan, pengantin baru, yang sedang berbulan madu dengan fasilitasfasilitas khusus dan tersendiri demi kenikmatan perjalanan dan kunjungan mereka.

Pendekatan Pariwisata,Terdapat empat pendekatan-pendekatan dalam pariwisata antara lain yaitu, (Spillane (1994) : 
a. Pendekatan Adaptancy,

Pendekatan

ini

menyebutkan

agar

pengaruh

negatif

pariwisata dapat dikontrol

dengan mencari bentuk

lain

perkembangan

pariwisata dari yang selama

ini sudah dikenal secara

umum, atau dengan

menyesuaikan pariwisata

dengan Negara atau daerah

tujuan wisata. Cara berpikir

baru ini berdasarkan

pandangan bahwa alam

dan budaya dapat

digabungkan dalam satu

konteks.

b. Pendekatan

Developmental,

Pendekatan Developmental atau sering disebut pendekatan Alternative ini menganggap bahwa

pariwisata dapat

disesuaikan dengan

keadaan masyarakat tuan

rumah dan peka akan

selera masyarakat tuan

rumah tersebut Dapat

dipercaya bahwa

perkembangan tersebut sebetulnya mempengaruhi pilihan wisatawan terhadap daerah tujuan wisatanya dan demikian juga kehidupan mereka didaerah tujuan wisata atau bentuk alternative pariwisata ini mempengaruhi jurang pemisah antara hak dan kewajiban dari tamu, tuan rumah dan perantaranya.

c. Pendekatan Advocasy, Pendekatan ini mendukung pariwisata dan menekankan keuntungan ekonomis dari pariwisata. Potensi pariwisata bisa dipakai untuk mendukung macam-macam kegiatan ekonomis, menciptakan lapangan kerja baru, memperoleh devisa asing yang dibutuhkan bagi pembangunan dan masih banyak lagi.

d. Pendekatan Cautionary,

Pendekatan ini

menekankan bahwa

pariwisata banyak

mengakibatkan banyak

kerugian (disbenefits) 


$$
\begin{aligned}
& \text { dalam berbagai aspek } \\
& \text { sosial-ekonomi: seperti } \\
& \text { menimbulkan lapangan } \\
& \text { kerja musiman dan kasar } \\
& \text { (rendahan), mengakibatkan } \\
& \text { kebocoran devisa asing, } \\
& \text { menyebabkan } \\
& \text { komersialisasi budaya, } \\
& \text { serta menyebabkan } \\
& \text { berbagai macam konflik. }
\end{aligned}
$$

\section{Objek Wisata}

Yoeti (1997) mendifinisikan objek wisata sebagai berbagai macam hal yang dapat dilihat, disaksikan, dilakukan atau dirasakan. Sedangkan Suwantoro (1997) mendifinisikan objek wisata sebagai potensi yang menjadi pendorong kehadiran wisatawan kesuatu daerah, dan objek wisata dibagi menjadi :

1. Obyek wisata dan daya tarik wisata alam, dimana obyek wisata ini memiliki daya tarik yang bersumber dari keindahan dan kekayaan alam.

2. Obyek wisata dan daya tarik budaya, dimana obyek dan daya tarik wisata ini bersumber dari kebudayaan, seperti peninggalan sejarah, museum, atraksi kesenian, dan obyek lain yang berkaitan dengan budaya.
3. Obyek wisata dan daya tarik pada minat khusus, dimana daya tarik dari obyek wisata ini bersumber dari minat khusus wisatawan itu sendiri, seperti olah raga, memancing dan sebagainya.

\section{Permintaan dan Penawaran Pariwisata}

\section{Definisi Permintaan}

Permintaan diartikan sebagai kemauan dan kemampuan pembeli untuk membeli barang/jasa.

Didalam permintaan terdapat hukum permintaan yang berbunyi "Pembeli akan membeli (meminta) lebih banyak barang ketika harganya turun dan akan membeli (meminta) lebih sedikit ketika harganya naik dengan menganggap hal lainnya tetap (Cateris Paribus)". Selain itu juga terdapat faktor-faktor yang mempengaruhi suatu permintaan dalam bentuk persamaan yaitu:

\section{$Q x=f(P x$, Py, I, T, E, Pop, Promosi)}

$\mathrm{Px}=$ Harga barang $\mathrm{X}$

Py = Harga barang lain (y) terkait

$1=$ Income

$\mathrm{T} \quad=$ Selera

$\mathrm{E} \quad=$ Ekspektasi harga barang $(\mathrm{x})$ yang

akan datang

Pop $=$ Populasi penduduk

Wahab (2003) membagi Permintaan pariwisata menjadi permintaan pariwisata 
potensial dan permintaan pariwisata actual, permintaan pariwisata potensial adalah sejumlah orang yang memenuhi anasir-anasir pokok suatu perjalanan dan karena itu mereka dalam keadaan siap untuk bepergian ke suatu Daerah Tujuan Wisata.

\section{Definisi Penawaran}

Penawaran diartikan kemauan dan kemampuan produsen untukmenawarkan suatu barang atau jasa untuk dijual

Didalam penawaran terdapat hukum penawaran yang berbunyi "Produsen akan menawarkan lebih banyak produk/barang untuk dijual ketika harganya naik dan akan menawarkan lebih sedikit produk/barang-nya ketika harganya turun.". Selain itu juga terdapat faktorfaktor yang mempengaruhi suatu penawaran yaitu:

a. Harga-harga faktor produksi

b. Harga barang terkait

c. Harga barang itu sendiri (Px). Hukum Penawaran mengatakan bahwa dengan menganggap hal lainnya tetap, kuantitas barang yang ditawarkan akan meningkat ketika harga barang tersebut meningkat.

d. Teknologi

e. Ekspektasi
Penawaran pariwisata memiliki ciri khas utama yaitu: penawaran jasa-jasa, yang ditawarkan sifatnya kaku dalam arti sulit mengubah sasaran penggunaan diluar pariwisata, penawaran pariwisata harus bersaing ketat dengan penawaran jasa-jasa lain

\section{Pendorong dan Penarik Pariwisata}

Goodal dalam Sharpley (1994), faktor pendorong merupakan faktor internal dalam diri individu (wisatawan) yang mempengaruhi yaitu kebutuhan dan keinginan seseorang yang memotivasi wisatawan untuk melakukan perjalanan wisata, sedangkan faktor penarik yang sesungguhnya merupakan faktor eksternal yang memotivasi wisatawan untuk mengadakan perjalanan wisata kesuatu daerah/objek wisata.

\section{Hubungan antara jumlah kunjungan wisatawan dengan variabel-variabel yang mempengaruhinya dalam penelitian}

1. Tingkat Inflasi, inflasi diartikan sebagai kenaikan harga barang pada periode waktu tertentu, keinginan wisatawan untuk berkunjung kesuatu tempat atau kesuatu daerah (objek wisata) tertentu akan dipengaruhi oleh harga-harga (naik atau turunya harga) 


\begin{abstract}
biasanya diukur dengan tingkat inflasi. Wisatawan akan memiliki motivasi yang tinggi untuk mengunjungi objek wisata ketika harga-harga turun atau stabil dan sebaliknya jika harga-harga naik (tinggi) atau terjadi inflasi maka motivasi/keinginan wisatawan untuk mengunjungi objek wisata akan turun, sehingga inflasi akan mempengaruhi jumlah kunjungan wisatawan.
\end{abstract}

2. Kurs Valuta Asing, kurs valuta asing merupakan ukuran mata uang yang satu dengan mata uang lainnya yaitu ukuran antara dollar Amerika terhadap rupiah. Banyak atau sedikitnya kunjungan wisatawan akan dipengaruhi oleh nilai kurs dollar amerika terhadap mata uang rupiah, bagi wisatawan mancanegara kunjungan mereka kesuatu daerah wisata biasanya membawa dollar amerika untuk keperluan transaksi karena dollar amerika merupakan mata uang kuat (hard currency) yang biasanya digunakan untuk teransaksi di setiap Negara, ketika nilai mata uang dollar amerika turun terhadap mata uang domestic (rupiah) atau nilai mata uang rupiah naik terhadap dollar amerika maka wisatawan asing akan mengeluarkan dollar lebih banyak dibandingkan ketika mata uang dollar naik nilainya terhadap mata uang domestic (rupiah) untuk setiap transaksinya sehingga akan mempengaruhi keinginan (motivasi) wisatawan mancanegara untuk berkunjung ke suatu daerah wisata.

\section{Nilai Produk Domestic Regional} Bruto (PDRB), merupakan ukuran pendapatan masyarakat suatu

daerah/kabupaten/provinsi, dimana ketika pendapatan masyarakat

(provinsi/kabupaten) meningkat maka keinginan untuk mengunjungi daerah wisatawan juga tinggi dan sebaliknya ketika pendapatan masyarakat (provinsi/kabupaten) turun maka keinginan untuk mengunjungi daerah wisatawan juga akan menurun sehingga besar atau kecilnya nilai PDRB 


$$
\begin{aligned}
& \text { maka akan mempengaruhi } \\
& \text { jumlah kunjungan wisatawan } \\
& \text { untuk berkunjung kesuatu objek } \\
& \text { wisata. }
\end{aligned}
$$

\section{METODE PENELITIAN}

\section{Jenis Penelitian}

Jenis penelitian yang digunakan dalam penelitian ini adalah penelitian eksplanatori yaitu penelitian yang bertujuan untuk mengetahui hubungan antara dua variabel atau lebih. Dengan penelitian ini maka akan dapat dibangun suatu teori yang dapat menjelaskan, dan meramalkan suatu gejala suatu variabel.

Penentuan lokasi penelitian dilakukan secara purposive sampling yaitu menentukan lokasi penelitian secara sengaja, lokasi penelitian adalah Kabupaten Lombok Utara (KLU)

\section{Jenis dan Sumber Data}

\section{Jenis data}

Jenis data dalam penelitian ini adalah :

a. Data kuantitatif yaitu data yang diperlukan dalam penelitian yang berupa angka angka yang dapat diukur besarnya dan dapat dihitung secara pasti seperti data PDRB, nilai tukar dan sebagainya

b. Data kualitatif yaitu data yang diperlukan dalam penelitian ini

berupa keterangan dan
kebijakan yang berkaitan
dengan pengembangan
pariwisata di kabupaten
Lombok utara (KLU)

\section{Sumber data}

data yang digunakan dalam penelitian ini adalah data sekunder, yaitu data yang pengguna tidak mengambil langsung dari responden/objek penelitian tetapi sudah dalam bentuk data jadi yang tersedia pada instansi atau lembaga pengumpul data seperti BPS, bank Indonesia, dan instansi lainnya penyedia data lainnya dengan data pengamatan dari tahun 2011-2016.

\section{Metode dan Teknik pengumpulan data}

Metode pengumpulan data yang digunakan dalam penelitian ini adalah metode studi kasus, dimana peneliti ingin mengetahui variable-variabel yang menentukan jumlah kunjungan wisatawan di kabupaten Lombok utara (KLU)

Teknik yang digunakan dalam mengumpulkan data dalam penelitian ini adalah sebagai berikut:

1. Dokumentasi yaitu pengumpulan data berupa catatan-catatan yang tersedia pada lembaga terkait

2. Study kepustakaan, yaitu pengumpulan data dengan cara penelahaan kepustakaan 
dengan obyek- obyek yang akan dibahas dan bahan bacaan yang berhubungan dengan masalah yang diteliti.

\section{Identifikasi dan Klasifikasi Variabel Identifikasi Variabel}

Variabel-variabel yang digunakan dalam penelitian ini adalah :

1. Jumlah kunjungan wisatawan domestic, satuan yang digunakan adalah wisatawan domestik (orang)

2. Tingkat Inflasi, satuan yang digunakan adalah persentase (\%)

3. Nilai Produk Domestic Regional Bruto (PDRB), satuan yang digunakan adalah rupiah (Rp)

\section{Klasifikasi Variabel}

Variabel yang digunakan dalam penelitian ini diklasifikasikan menjadi :

1. Variabel Dependen/Variabel Terikat $(Y)$, merupakan variabel yang dipengaruhi oleh variabel lain (variabel independen/bebas). Dalam penelitian ini variabel yang menjadi variabel dependen adalah jumlah kunjungan wisatawan domestic (dalam negeri)

2. Variabel Independen/Variabel bebas (X), merupakan variabel yang mempengaruhi variabel variabel dependen/terikat. Dalam penelitian ini variabel yang menjadi variabel independen adalah Variabel tingkat inflasi provinsi (X1), ,nilai PDRB provinsi (X2), tingkat inflasi kabupaten (X3), nilai PDRB kabupaten (X4).

\section{Definisi operasional variabel}

1. Jumlah kunjungan wisatawan. Variabel jumlah kunjungan wisatawan yang digunakan dalam penelitian ini menggunakan data banyaknya jumlah kunjungan wisatawan domestic (dalam negeri) setiap tahun dengan satuan (orang)

2. Tingkat Inflasi (Provinsi NTB). Inflasi merupakan kenaikan harga barang secara terus-menerus, Inflasi yang digunakan dalam penelitian ini menggunakan inflasi tahuhan dengan satuan yang digunakan adalah persentase (\%).

3. Tingkat Inflasi (KLU). Inflasi merupakan kenaikan harga barang secara terusmenerus, Inflasi yang digunakan dalam penelitian ini menggunakan inflasi tahuhan dengan satuan yang digunakan adalah persentase (\%).

4. Nilai Produk Domestic Regional Bruto (PDRB) Provinsi. variabel ini merupakan produk yang dihasilkan oleh masyarakat suatu daerah (provinsi) dalam perekonomiannya, dimana PDRB juga menjadi ukuran pendapatan masyarakat di dalam suatu daerah 
(Provinsi), satuan yang digunakan untuk PDRB adalah rupiah (Rp).

5. Nilai Produk Domestic Regional Bruto (PDRB) Kabupaten. variabel ini merupakan produk yang dihasilkan oleh masyarakat suatu daerah (kabupaten) dalam perekonomiannya, dimana PDRB juga menjadi ukuran pendapatan masyarakat di dalam suatu daerah (kabupaten), satuan yang digunakan untuk PDRB adalah rupiah (Rp).

\section{Teknik Analisis Data}

\section{Analisis Vector Auto Regression (VAR)}

1. Model VAR secara umum digambarkan secara matematis sbb:

$\mathrm{x}_{\mathrm{t}}=\alpha \mathrm{i}+\sum_{j=1}^{k} \quad \beta_{\mathrm{i}}+\mathrm{X}_{\mathrm{t}-1}+\mathrm{e}_{\mathrm{t}}$

$x_{t}=$ Vektor variabel Endogen/dependen

ai $=$ vector variabel

Eksogen/independen dan Konstanta (intercept)

$\beta_{i}=$ Matrix koefisien

$\mathrm{e}_{\mathrm{t}}=$ Vektor Residu

Langkah-langkah dalam Proses Analisis Analisis Vector Auto Regression (VAR) sbb: a. Data terlebih dahulu ditransformasikan ke dalam bentuk logaritma (Ln)

b. Melakukan uji stasioneritas variabel dengan menggunakan uji akar unit (unit roots) metode ADF, dimana ADF statistic dibandingkan dengan critical value Mac Kinnon dengan tingkat signifikansi 5\%.

c. Menentukan Lag Optimum dengan melihat lag terpendek dengan menggunakan Schwarz Information Criterion (SC)

d. Uji Kointegrasi antar variabel, ketika tidak terjadi kointegrasi antar variabel maka VAR hanya dapat dilakukan pada turunan pertamanya

2. Model Vector Auto Regression (VAR) untuk jumlah kunjungan wisatawan domestic

a. Model Vector Auto Regression (VAR) untuk Permintaan kunjungan wisatawan domestic

PerKWD $_{t}=-a_{1}+\beta_{1 i}$ PerKWD $_{t-i}+\beta_{1 i}$

$\operatorname{infP}_{t-i}+\beta_{1 i}$ PDRBp $_{t-i}+$ ei

$\operatorname{InfP}_{t}=a_{2}+\beta_{2 i}$ PerKWD $_{t-i}+\beta_{2 i} \operatorname{GinfP}_{t-i}$

$+\beta_{2 i}$ PDRBp $_{t-i}+e i$

PDRBp $_{t}=a_{3}+\beta_{3 i}$ PerKWD $_{t-i}+\beta_{3 i}$ infP $_{t-}$

$i+\beta_{3 i}$ PDRBp $_{t-i}+e i$

b. Model Vector Auto Regression (VAR) untuk Penawaran kunjungan wisatawan domestic di Kabupaten Lombok Utara

PenKWD $_{t}=a_{1}+\beta_{1 i}$ PenKWD $D_{t-i}+\beta_{1 i}$ $\operatorname{infK}_{t-i}+\beta_{1 i} P P_{R B k_{t-i}}+$ ei

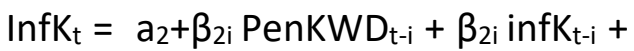
$\beta_{2 i}$ PDRBk $_{t-i}+$ ei

PDRBk $_{t}=a_{3}+\beta_{3 i}$ PenKWD $_{t-i}+\beta_{3 i}$ infK $_{t-}$ $i+\beta_{3 i}$ PDRBk $_{t-i}+e i$ 
ANALISIS HASIL DAN PEMBAHASAN

\section{Analisis Hasil Penelitian}

\section{Analisis VAR untuk model pertama}

1. Model Vector Auto Regression (VAR) untuk Permintaan kunjungan wisatawan domestic (PerKWD) di Kabupaten Lombok Utara

PerKWD $D_{t}=-3665,91+0,8872$ PerKWD $_{t-\mathrm{i}}$ $+4,2706$ infP $_{t-i}+0,0011$ PDRBp $_{t-i}+$ ei $\operatorname{InfP}_{t}=-0,0238+0,8872 P$ erKWD $D_{t-i}+$ 4,2706infP $t_{t-i}+0,0011$ PDRBp $_{t-i}+$ ei PDRBp $_{t}=249005,2+0,8872$ PerKWD $_{t-i}$ $+4,2706$ infP $_{t-i}+0,0011$ PDRBp $_{t-i}+$ ei

2. Menguji stasioner dari model VAR pertama

Dengan criteria jika titik-titik atau akar unit terletak di dalam lingkaran atau kurang dari 1, maka model VAR tersebut dinyatakan stasioner dan jika titik-titik atau akar unit terletak di luar lingkaran atau lebih dari 1, maka model VAR tersebut dinyatakan tidak stasioner. Dari olahan eviews (pada lampiran) terlihat bahwa titik-titik atau akar unit terletak di dalam lingkaran atau kurang dari 1, maka model VAR tersebut dinyatakan lolos uji stasioner.

3. Menguji Kausalitas Granger dari model VAR pertama

Uji ini digunakan untuk melihat hubungan atau pengaruh antar variabel, pada lampiran terlihat bahwa Dengan alpha 5\% (0.005), maka PerKWD dipengaruhi oleh Inflasi Provinsi, Inflasi Provinsi dipengaruhi juga oleh PDRB Provinsi dengan nilai 0,010 atau kurang dari $5 \%(0.005)$

\section{Analisis VAR untuk model kedua}

1. Model Vector Auto Regression (VAR) untuk Penawaran kunjungan wisatawan domestic (PenKWD) di Kabupaten Lombok Utara PenKWD $D_{t}=-3665,91+0,8872 P^{2}$ enKWD $D_{t-i}$ $+54,50$ infK $_{t-i}+0,0041 P R_{R B k} k_{t-i}+$ ei $\operatorname{InfK}_{\mathrm{t}}=-4,2503+0,8872$ PenKWD $_{\mathrm{t}-\mathrm{i}}+$ 54,50infK $\mathrm{t}_{\mathrm{t}-\mathrm{i}}+$ 0,0041PDRBk $\mathrm{t}_{\mathrm{t}-\mathrm{i}}+$ ei PDRBk $_{\mathrm{t}}=148010,9+0,8872$ PenKWD $_{\mathrm{t}-\mathrm{i}}$ $+54,50$ infK $_{\mathrm{t}-\mathrm{i}}+0,0041$ PDRBK $_{\mathrm{t}-\mathrm{i}}+\mathrm{ei}$

2. Menguji stasioner dari model VAR kedua

Dengan kriteria jika titik-titik atau akar unit terletak di dalam lingkaran atau kurang dari 1, maka model VAR tersebut dinyatakan stasioner dan jika titik-titik atau akar unit terletak di luar lingkaran atau lebih dari 1, maka model VAR tersebut dinyatakan tidak stasioner. Dari olahan eviews (pada lampiran) terlihat bahwa titik-titik atau akar unit terletak di dalam lingkaran atau kurang dari 1, maka model VAR tersebut dinyatakan lolos uji stasioner. 
3. Menguji Kausalitas Granger dari model VAR Kedua

Uji ini digunakan untuk melihat hubungan atau pengaruh antar variabel, pada lampiran terlihat bahwa Dengan alpha 5\% (0.005), maka PenKWD dipengaruhi oleh Inflasi Kabupaten KLU, Inflasi Kabupaten KLU dipengaruhi juga oleh PDRB Kabupaten Lombok Utara dengan nilai 0,048 atau kurang dari $5 \%(0.005)$.

\section{Pembahasan}

Dari analisis regresi berganda model pertama dengan menggunakan variabelvariabel independen (Inflasi Provinsi, PDRB Provinsi) dan variabel dependen yang digunakan adalah Jumlah Permintaan kunjungan wisatawan domestik (PerKWD), maka faktor-faktor yang mempengaruhi jumlah kunjungan wisatawan domestik adalah: Variabel PDRB Provinsi, dengan nilai $t$ hitung $(12,45)$ dari variabel PDRB Provinsi lebih besar dari t tabel $(1,68)$, dengan tingkat signifikansi $0,000<\alpha=0,05$, maka Ho di diterima dan $\mathrm{Ha}$ ditolak. hal ini berarti Variabel PDRB Provinsi memiliki pengaruh yang signifikan terhadap Jumlah Permintaan kunjungan wisatawan domestic di Kabupaten Lombok Utara (KLU)
Sedangkan dari analisis regresi berganda model Kedua dengan menggunakan variabel-variabel independen (Inflasi Kabupaten Lombok Utara, PDRB Kabupaten Lombok Utara) dan variabel dependen yang digunakan adalah Penawaran kunjungan wisatawan Domestik (PenKWD), maka faktor-faktor yang mempengaruhi Penawaran kunjungan wisatawan domestic di kabupaten Lombok utara (KLU) adalah: Variabel PDRB Kabupaten Lombok Utara, dengan nilai t hitung $(5,83)$ dari variabel PDRB lebih besar dari $\mathrm{t}$ tabel $(1,68)$, dengan tingkat signifikansi $0,000<\alpha=$ 0,05, maka Ho di diterima dan Ha ditolak. hal ini berarti Variabel PDRB Kabupaten Lombok Utara memiliki pengaruh yang signifikan terhadap Penawaran kunjungan wisatawan Domestik di Kabupaten Lombok Utara (KLU)

Dari analisis Vector Autogresive (VAR) untuk model pertama dengan menggunakan variabel-variabel independen (Inflasi Provinsi, PDRB Provinsi) dan variabel dependen yang digunakan adalah Permintaan kunjungan wisatawan domestik (PerKWD), maka faktor yang paling mempengaruhi Permintaan kunjungan wisatawan domestic adalah variabel Inflasi Provinsi, dimana hubungan ini terlihat dari uji 
kausalitas Granger dengan nilai 0,010 atau kurang dari 5\% (0.005), Sedangkan analisis Vector Autogresive (VAR) untuk model kedua dengan menggunakan variabel-variabel independen (Inflasi provinsi, PDRB provinsi) dan variabel dependen yang digunakan adalah Penawaran kunjungan wisatawan domestik (PenKWD), maka faktor yang paling mempengaruhi Penawaran kunjungan wisatawan domestik adalah variabel Inflasi, dimana hubungan ini terlihat dari uji kausalitas Granger dengan nilai 0,048 atau kurang dari 5\% (0.005).

Artinya pemerintah daerah harus benarbenar menjaga dan memperhatikan variabel Inflasi karena akan menentukan biaya atau cost yang akan dikeluarkan oleh masyarakat yang ingin berwisata khususnya ke kabupaten Lombok utara (KLU), daerah Nusa Tenggara Barat (NTB) dan daerah-daerah lain di Indonesia pada umumnya.

\section{KESIMPULAN DAN SARAN}

\section{Kesimpulan}

1. Dari Analisis Uji Statistik model pertama diketahui bahwa variabel atau faktor-faktor yang mempengaruhi Permintaan kunjungan wisatawan Domestik di Kabupaten Lombok Utara (KLU) adalah Variabel Inflasi Provinsi dengan tingkat signifikansi $0,008<$ $\alpha=0,05$, Variabel PDRB Provinsi dengan tingkat signifikansi $0,000<$ $\alpha=0,05$, Hal ini berarti Variabel Inflasi Provinsi, PDRB Provinsi memiliki pengaruh yang signifikan terhadap Permintaan kunjungan wisatawan Domestik di Kabupaten Lombok Utara (KLU)

2. Dari Analisis Uji Statistik model kedua diketahui bahwa variabel atau faktor-faktor yang mempengaruhi Penawaran kunjungan wisatawan domestik di Kabupaten Lombok Utara (KLU) adalah Variabel Inflasi Kabupaten dengan tingkat signifikansi $0,008<$ $\alpha=0,05$, Variabel PDRB kabupaten dengan tingkat signifikansi $0,000<$ $\alpha=0,05$, Hal ini berarti Variabel Inflasi kabupaten, PDRB kabupaten memiliki pengaruh yang signifikan terhadap Penawaran kunjungan wisatawan domestik di Kabupaten Lombok Utara (KLU)

3. Variabel yang menentukan permintaan kunjungan wisatawan Domestik di Kabupaten Lombok Utara (KLU) dengan menggunakan analisis Vector Autogresive (VAR) model pertama adalah variabel 
Inflasi Provinsi, dimana hubungan atau pengaruhnya terlihat dari uji kausalitas Granger dengan nilai 0,010 atau kurang dari 5\% (0.005).

4. variabel yang paling dominan mempengaruhi Penawaran kunjungan wisatawan domestik di Kabupaten Lombok Utara (KLU) dengan menggunakan analisis Vector Autogresive (VAR) model kedua adalah variabel Inflasi kabupeten, dimana hubungan atau pengaruhnya terlihat dari uji kausalitas Granger dengan nilai 0,048 atau kurang dari $5 \%(0.005)$.

\section{Saran}

1. Penelitian terhadap factor-faktor yang mempengaruhi permintaan dan penawaran kunjungan wisatawan di Kabupaten Lombok Utara (KLU) masih sangat kurang sehingga diperlukan adanya penambahan variabel di dalam penelitian ini bagi peneliti selanjutnya, agar aspek-aspek lain di dalam variabel yang paling mempengaruhi jumlah kunjungan wisatawan di Kabupaten Lombok Utara (KLU) yang belum tercantum dalam penelitian ini agar dimasukkan sebagai variabel penelitian untuk menghasilkan penelitian yang lebih komprehensip.

2. Perlu adanya tindak lanjut dari pemerintah Kabupaten Lombok Utara (KLU) maupun Pemprov NTB dalam Menjaga stabilitas ekonomi daerah baik kabupaten maupun provinsi terutama variabel PDRB dan Inflasi provinsi dan Inflasi dan PDRB KLU karena akan mempengaruhi jumlah permintaan dan penawaran kunjungan wisatawan, sehingga masyarakat akan lebih mudah untuk dapat berwisata ke daerah-daerah yang diinginkan terutama di Kabupaten Lombok Utara (KLU).

3. Bagi pemerintah Pusat juga harus benar-benar menjaga stabilitas perekonomian nasional yaitu PDB dan Inflasi secara nasional, karena akan menentukan biaya atau cost yang akan dikeluarkan oleh masyarakat yang ingin berwisata khususnya ke daerah Nusa Tenggara Barat (NTB) khususnya ke daerah-daerah wisata di kabupaten Lombok utara. 


\section{DAFTAR PUSTAKA}

Anonin. Undang-Undang No. 10 Tahun 2009 Tentang Kepariwisataan

Ali Ibrahim, Mohammed.The Determinants of International Tourism Demand for Egypt: Panel Data Evidence. European Journal of Economics, Finance and Administrative Sciences ISSN 1450-2275 Issue 30 (2011)

Emilia Gabroveanu et,al. Analysis of Main Economic Factors Influence on Romanian Tourists Number Accommodated in Romania, using Anova Method. Theoretical and Applied Economics Journal 2010

Kuncoro,Mudrajad.2003. Metode Riset Untuk Ekonomi dan Bisnis.Erlangga.Jakarta

Marpaung, Happy. 2002. Pengetahuan Kepariwisataan. Alpabeta Bandung.

Pitana, dkk. 2009. Pengantar IImu Pariwisata. CV Andi Offset: Yogyakarta

Pendit, Nyoman. 1999. Ilmu Pariwisata Sebuah Pengantar Perdana. PT. Pradnya Paramita. Jakarta

Raymond Y.C. Tse. Estimating the impact of economic factors on tourism: evidence from Hong Kong. Tourism Economics Journal, 2001, 7 (3), 277-293

Suwantoro, Gamal, 1997. Dasar-dasar Pariwisata. ANDY. Yogyakarta

Spillane. James. 1994. Pariwisata Indonesia : Siasat Ekonomi dan Rekayasa Kebudayaan. Kanisius. Yogyakarta.

Sharpley. 1994. Tourism, Tourism and Socciety. Huntingdom: ELM Publication

Soekadijo, R. G, 1997. Anatomi Pariwisata : Memahami Pariwisata Sebagai Sistem Linkage. Gramedia Pustaka Utama. Jakarta.

Sharifi \& Gilaninia.Economic Factors Affecting Tourism Supply. International Journal of Business and Behavioral Sciences Vol. 3, No.10; October 2013

Wijaya,I Nengah. Pengaruh Jumlah Wisatawan Mancanagera, Lama Tinggal, Dan Kurs Dollar Amerika Terhadap Penerimaan Produk Domestik Regional Bruto Industry Pariwisata Kabupaten Badung Tahun 1997-2010. Tesis Pascasarjana Universitas Udayana 2011

Yoeti, Oka,A 1997. Perencanaan dan Pengembangan Pariwisata. PT. Pradnya Paramita. Jakarta.

Yoeti, Oka, A. 2006. Pengantar Ilmu Pariwisata. Bandung, Angkasa. 